Journal of the Society for the Study of Architecture in Canada Le Journal de la Société pour l'étude de l'architecture au Canada

\title{
Minority Immigrant Narratives in Saskatchewan: Kaposvar Roman Catholic Church and Bekevar Presbyterian/Reformed Church
}

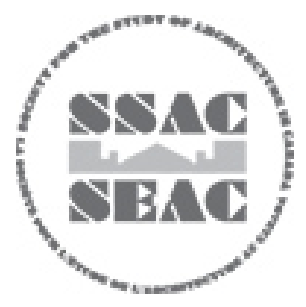

Kristie Dubé

Volume 43, numéro 1, 2018

Religious Architecture in Canada

URI : https://id.erudit.org/iderudit/1049408ar

DOI : https://doi.org/10.7202/1049408ar

Aller au sommaire du numéro

Éditeur(s)

SSAC-SEAC

ISSN

2563-8696 (numérique)

Découvrir la revue

Citer cet article

Dubé, K. (2018). Minority Immigrant Narratives in Saskatchewan: Kaposvar Roman Catholic Church and Bekevar Presbyterian/Reformed Church. Journal of the Society for the Study of Architecture in Canada / Le Journal de la Société pour l'étude de l'architecture au Canada, 43(1), 57-63.

https://doi.org/10.7202/1049408ar 


\section{MINORITY IMMIGRANT NARRATIVES IN SASKATCHEWAN: KAPOSVAR ROMAN CATHOLIC CHURCH AND BEKEVAR PRESBYTERIAN/REFORMED CHURCH}

KRISTIE DUBÉ received her M.A. in history from the University of Regina, and is currently pursuing her Ph.D. in humanities at York University. Her interests focus on medieval revival religious architecture in western Canada.

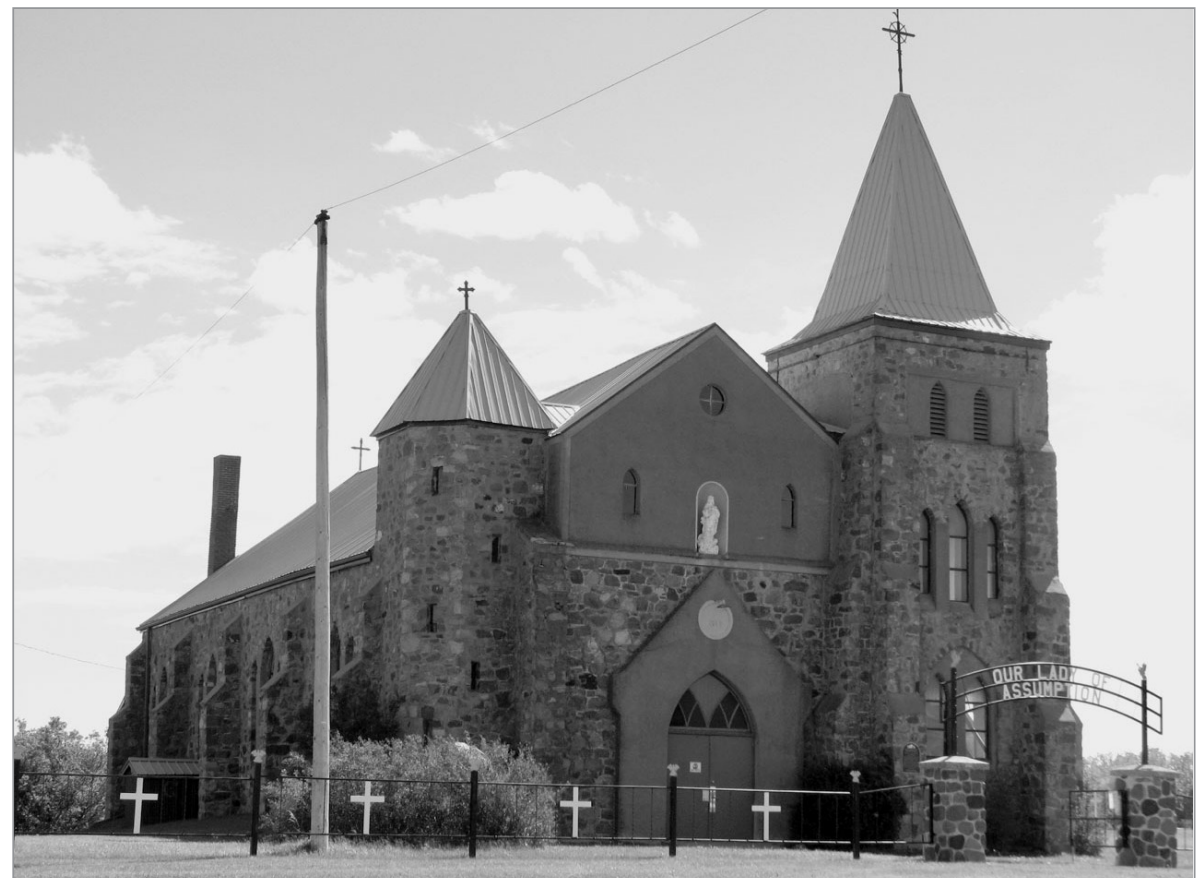

FIG. 1. VIEW OF THE NORTH SIDE OF KAPOSVAR ROMAN CATHOLIC CHURCH, KAPOSVAR, RM 183, SK (1906-1907). UNKNOWN ARCHITECT, PIROT STONEMASONS. | KRISTIE DUBÉ.
> KRISTIE DUBÉ

E arly nineteenth-century historian František Palacký noted that "monuments, which record the history of a nation, have but one life, never to be recreated once destroyed."1 Saskatchewan's late nineteenth- and early twentieth-century church architecture is more often than not constructed in wood, isolated, and vulnerable to the elements; therefore, it is important to examine each remaining structure for the history it holds before it is lost. Even in a single building, there is a multitude of possible stories, and the nature of the story shifts depending on what themes one wishes to explore. For instance, in order to explore the connections between twentieth-century churches across Saskatchewan, it would make sense to choose a common point to narrow things down, for example belonging to the same denomination or the same architect. This macro-history approach would result in an examination of commonalities centred on a main theme, such as an architect or denomination. The advantages of this kind of approach are a clear theme and focus, as well as the ability to bring otherwise distant structures under a justifiable common branch.

However, there are disadvantages to these macro-themed approaches as well. In an architect-centred approach, the tendency is to focus on the common elements of the architect's motivations across the various structures, at the expense of the motivations of more disparate groups. While this disadvantage may not seem to be initially significant, it can be extremely important when the larger picture is considered. In the case 


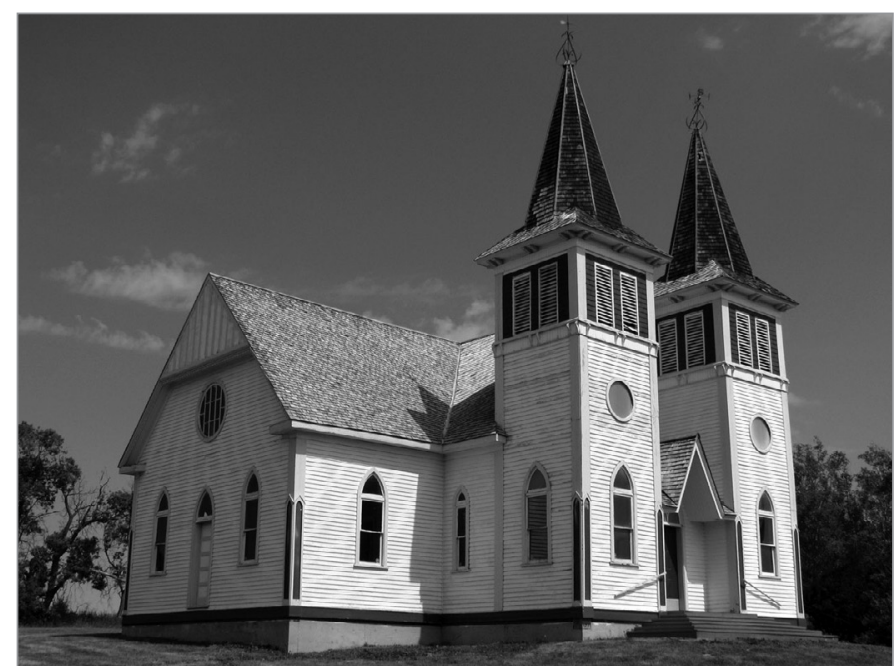

FIG. 2. VIEW OF THE WEST FAÇADE OF BEKEVAR PRESBYTERIAN CHURCH, BEKEVAR, RM 94, SK (1912). UNKNOWN ARCHITECT. | KRISTIE DUBÉ.

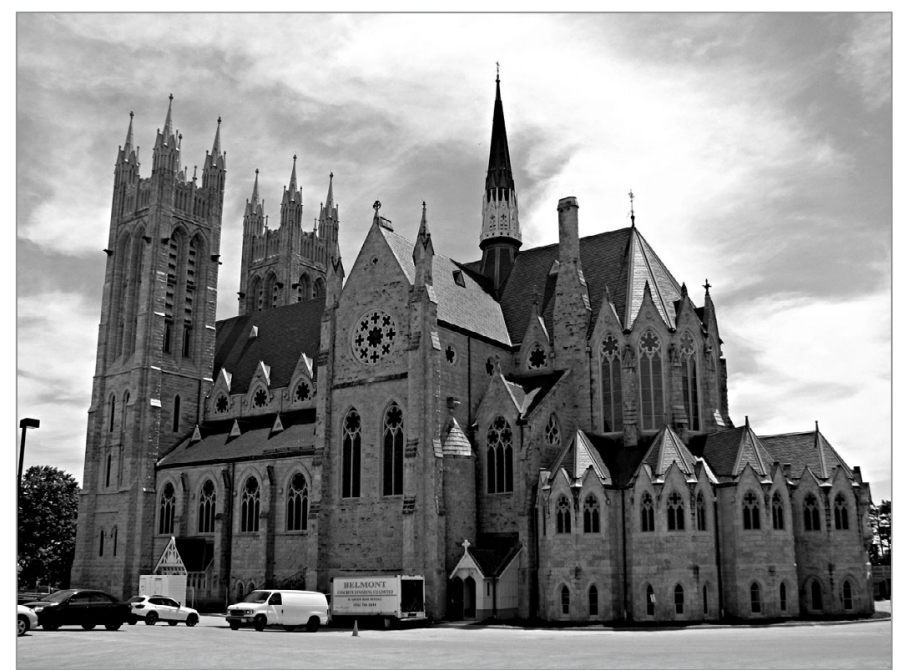

FIG. 3. VIEW OF SOUTH SIDE OF CHURCH OF OUR LADY OF THE IMMACULATE CONCEPTION IN GUELPH, ON (1876-1888). ARCHITECT: JOSEPH CONNOLLY. | KRISTIE DUBÉ. of late nineteenth- and early twentiethcentury Canadian religious architecture, favouring a denominational theme results in a focus on the motivations of the French- or English-speaking clergy. While useful in understanding the larger movements of complex religious organizations during a dynamic period, this approach can also result in the perpetuation of an Anglo/French-normative perspective, at the expense of the minority immigrant narratives of the congregations. This consequence is particularly possible with Saskatchewan's early built heritage due to the often disparate motivations of the English/French clergy and the ethnic minority congregations. Consequently, I propose an alternative perspective, one that uses a micro-history approach, in order to rediscover these minority immigrant stories. In the interest of demonstrating the extent of the immigrant narratives that can be uncovered, I will here re-examine two structures that I have already explored in the traditional denominational/architect-driven approach, Kaposvar Roman Catholic Church ([Rural Municipality] RM 183, 1906-1907, fig. 1) and Bekevar Presbyterian/Reformed Church (RM 94,
1912, fig. 2). ${ }^{2}$ These two structures, in particular, reveal the immigrants' desire to create a strong Hungarian/Belgian foothold within Canada, one that echoed the brightest achievements of their native land. ${ }^{3}$

Churches, by their very nature, are buildings dedicated to a higher power, and as such are often tied to notions of the future, both during one's lifetime and in the afterlife. More often than not, the resulting aspirations are full of hope for a brighter future. However, as churches are the product of the efforts of many people, they hold more than one set of aspirations. In this article, it would be impractical to try to discuss all the possible narratives, important as they are. In Saskatchewan's early twentieth-century rural churches, the easiest stories to access are usually those of the priest/pastor or the clergy. ${ }^{4}$ This is understandable as the clergy tend to leave more written documentation describing their efforts. Also, they are often highly involved in the decisions made during the construction of a new church, making them an ideal focus for an architectural historian. However, the clergy's goals are not necessarily synonymous with the aspirations of the largest group of stakeholders, the congregation itself. In the case of a minority immigrant congregation, a disparity of aspirations between the two groups is even more likely, as their cultural backgrounds/experiences/languages oftentimes differ. Consequently, it is imperative that more focus be given to these immigrant narratives in order to ensure that the diverse history of Saskatchewan's churches is properly depicted.

In the case of the Kaposvar Roman Catholic Church (1906-1907, fig. 1), two immigrant groups inserted narratives of particular interest into the church. The first concerns the priest responsible for overseeing the construction, Jules Pirot. French-speaking priests were the main voice of the Roman Catholic Church in the region since the 1890s. The Roman Catholic Archdiocese of St. Boniface, Manitoba, in particular, held a great deal of influence thanks to Father Page assisting in the construction of Kaposvar's first church (a simple log structure of seven by fifteen metres, with a freestanding bell tower) in $1894 .^{5}$ 
It could be expected, then, that the new church might similarly fall under their influence. Archbishop Adélard Langevin of St. Boniface did comment on the church once it was finished, stating that there was no "finer rural church, belonging to any denomination," in all of Western Canada. ${ }^{6}$ While it is a very positive review, there is no evidence that St. Boniface had any direct involvement in the construction process of the new church itself. What is evident is that Archbishop Langevin was interested in applauding the construction of Kaposvar's new church, but it is likely that he merely promoted the church as part of his larger role of expanding Catholic influence in the region. ${ }^{7}$ An approach based on a denominational theme would therefore have only shown that St. Boniface and Kaposvar were connected under the larger umbrella of Roman Catholic efforts to expand across the Prairie west. While this does show the importance of considering Prairie structures as part of a larger mission of expansion across the region, it does little to tease out the particulars of Kaposvar church itself. Instead, we must look to other sources to discover Kaposvar's distinct story.

The largest group involved with the construction of Kaposvar Church is, of course, the congregation itself, which in this instance was predominantly Hungarian. The settlement of the region was not an organic process, but, rather, a planned affair. An immigration agent by the name of Count Paul Oscar Esterhazy purchased 125,000 acres of land in 1886 with the purpose of forming a colony for Hungarians. ${ }^{8}$ The first wave of immigrants were Slovak or Hungarian-Slovenians miners in Pennsylvania, who came as a result of a letter that Esterhazy sent to their communities. ${ }^{9}$ The second wave of immigrants came after a pamphlet blitz by the Department of the Interior under the direction of Cliford Sifton. The pamphlet was written by Esterhazy and contained inflated depictions of conditions in the region, alongside stories of settlers being ill-treated or unable to find employment in the United States. ${ }^{10}$ The somewhat disingenuous campaign was successful and, by the early 1900s, Kaposvar and its neighbouring community of Esterhazy had 900 settlers, 200 homesteads, and 14,000 acres under cultivation. ${ }^{11}$ Eight hundred of those belonged to the Kaposvar Catholic congregation, which was predominantly Hungarian. ${ }^{12}$

The Hungarian congregation's narratives are most apparent in the façade of the church. Firstly, it is important to note that the impressive façade uses a twin-towered design. Generally, a twintowered motif was reserved for cathedral churches. The use of such a motif in a parish church is not unique; for instance, Joseph Connolly's Church of Our Lady of the Immaculate Conception in Guelph, Ontario (1876-1888, fig. 3), is a notable example. However, the use of a great church motif in a smaller church is used to make a statement. ${ }^{13}$ It demonstrates that the congregation wanted their structure to be considered alongside prominent cathedral churches, and had great hopes for its future success.

Evidence of the congregation's involvement in the construction of the church is found in the particulars of the design of the façade, where links to the great churches of their native homeland are evident. The most likely source of inspiration was the great coronation Church of Our Lady (Matthias) in Budapest (fourteenth century, fig. 4). The general massing of the façade, with the northern tower being substantially lower than the southern one is quite similar, albeit simpler in design (figs. 1 and 4). It was common for churches to begin construction with the

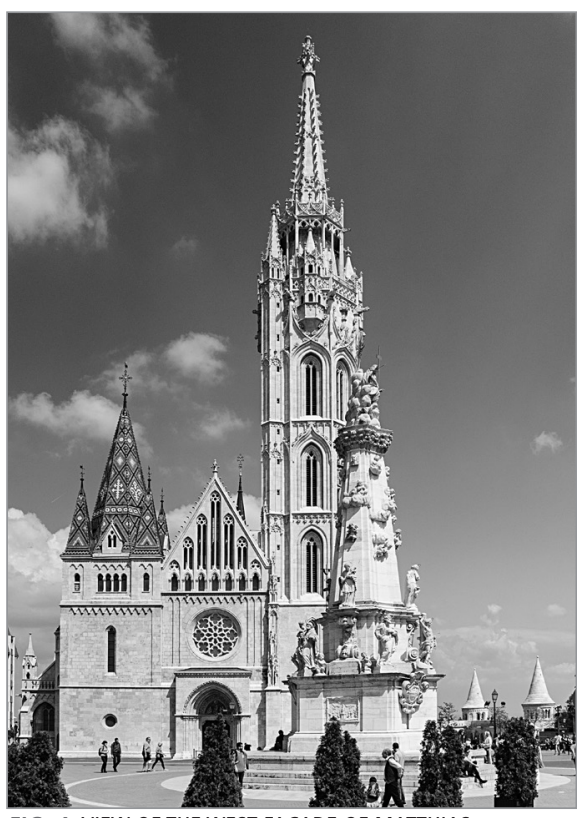

FIG. 4. VIEW OF THE WEST FAÇADE OF MATTHIAS CORONATION CHURCH, BUDAPEST, HUNGARY (14 ${ }^{\text {TH }}$ (ENTURY). | STEFAN SCHÄFER, LICH.

intention of erecting a larger spire, only to end up having to settle for a smaller one due to lack of funds. However, at Kaposvar there is no evidence of multiple building stages. Furthermore, it is clear from the much smaller proportions of the base of the northern tower that uneven towers were the intended design from the start, showing a desire to link their congregation to Matthias Church. Furthermore, Kaposvar's central block, while not an exact copy, shares a similar flat design with a pitched roof and a single entrance framed by a pointed arch. Matthias Church was heavily restored from 1873-1896 by Frigyes Schulek, and while I have yet to find evidence of publication, the high profile of the church as a coronation structure means it is very likely that it was very well known at the time. Matthias Church's royal associations linked Kaposvar to Hungary's highest power. With this connection, it is no wonder that Archbishop Langevin gave Kaposvar such high praise. The Hungarian 


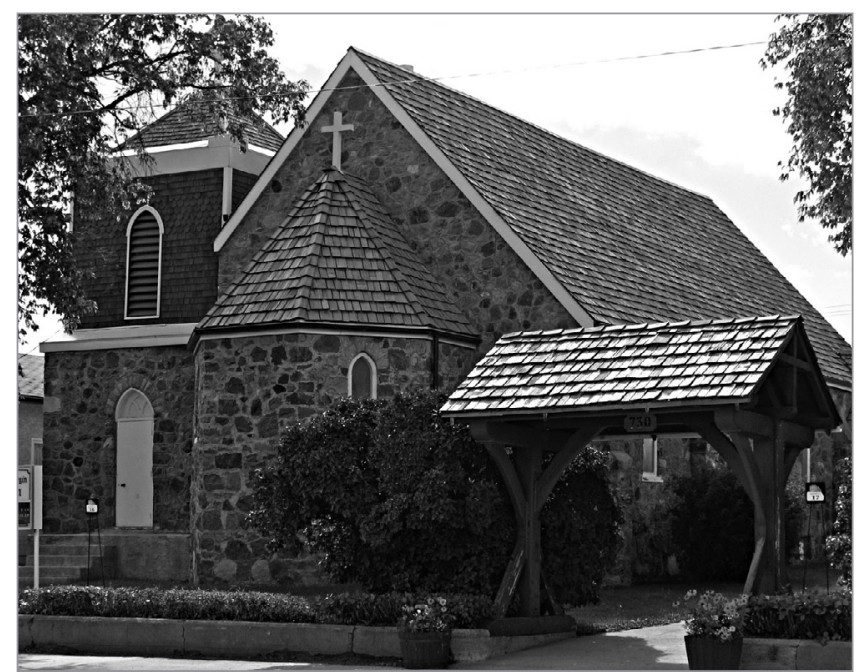

FIG. 5. VIEW OF WEST FAÇADE OF ST. MARY THE VIRGIN ANGLICAN CHURCH, WHITEWOOD, SK (1902). UNKNOWN ARCHITECT. | KRISTIE DUBÉ.

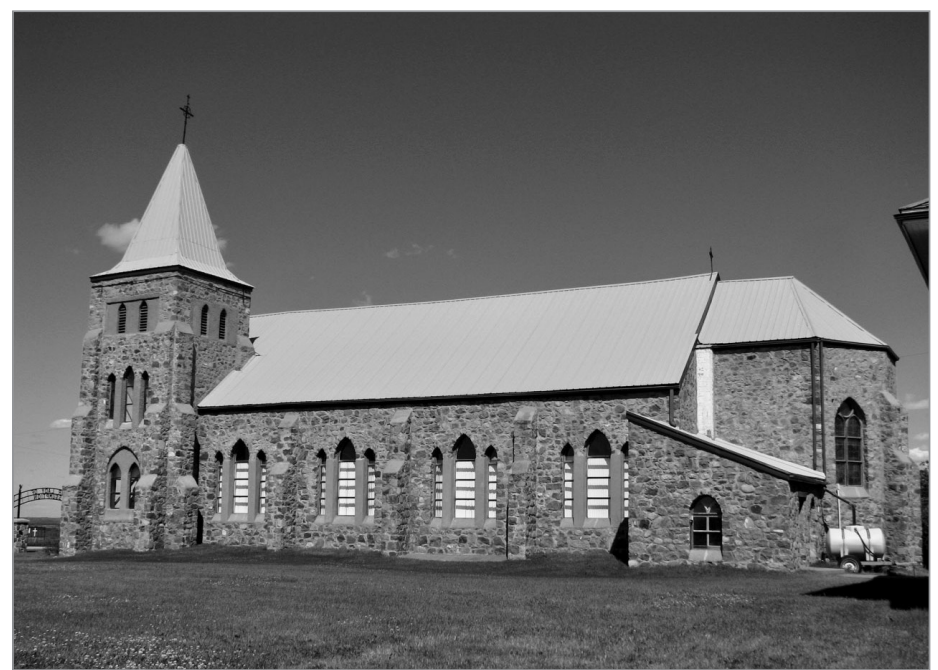

FIG. 6. VIEW OF THE SOUTH SIDE OF KAPOSVAR ROMAN CATHOLIC CHURCH, KAPOSVAR, RM 183, SK (1906-1907). UNKNOWN ARCHITECT, PIROT STONEMASONS. | KRISTIE DUBÉ. narrative held within the façade showed unlimited ambition for the future of the congregation and the colony, one on par with the highest glories of their homeland.

Interestingly, despite the fact that the congregation was predominantly Hungarian, the structure also shows evidence of Belgian influence. A small group of Belgian immigrants were able to weave their own narrative into its construction, thanks to their influential positions. The priest responsible for Kaposvar during the construction of the new church was a French-speaking Belgian, Jules Pirot. The previous church had been a simple log structure, and while it was expected that the new church would be somewhat grander, there were some challenges. ${ }^{14}$ The only readily available construction materials in the region were wood and fieldstone. Due to a scarcity of skilled labour, fieldstone was only used for farm homesteads or churches that were relatively simple and small, such as St. Mary the Virgin Anglican Church in Whitewood (1902, fig. 5). It is not clear who was the driving force behind the grand design, but Pirot himself returned to Belgium to enlist the services of his stonemason brothers (Alphonse, Camille, Lucien, and brother in-law Octive Willaume). ${ }^{15}$ Without their assistance, Kaposvar's complex design and size would not have been tenable.

As Pirot and his family were fairly crucial to the process, they were able to insert their own narrative into Kaposvar Church. The nave windows are a rather unusual pattern of triple lancets in an ABA configuration (fig. 6). Some of the few known parallels are found in the Scheldt/Tournai region of Belgium, in thirteenth-century churches such as Our Lady of Pamele in Oudenaarde (1234-1264, fig. 7). ${ }^{16}$ Our Lady of Pamele Church is fairly obscure but it had been featured in a monograph (L'Église de Notre-Dame-de-Pamela à Audenarde) in 1883 and thus would have been fairly well known in Belgium. ${ }^{17}$ It is possible that this region was the Pirot family homeland, or perhaps that they were just inspired by the monograph. Either way, they clearly wanted to transplant part of their own culture into Saskatchewan. When the complexity and size of Kaposvar is considered, it is clear that it was only possible due to their expertise, therefore, the grandeur of the church becomes part of the Belgian narrative as well. After all, it is unlikely that they made the journey without having some idea beforehand about the job. The aspirations of the Belgian brothers must have been just as high as those of the Hungarians, both striving for the brightest of futures in Canada. Kaposvar Church, their beacon of hope, was possible due to the joint efforts of both the Hungarians and the Belgians.

Bekevar Presbyterian Church (RM 94, 1912, fig. 2) was constructed in a nearby Hungarian colony. The level of prosperity at Bekevar was less than at Kaposvar, but the congregation still managed to insert a distinctly Hungarian flavour into their church. The colony was formed in 1900 by Jano Szabo as a Hungarian Reformed (Calvinist) grouping, and drew settlers from Hungarian towns such as Szabo's hometown of Botragy, as well as Whitewood, Saskatchewan. ${ }^{18}$ Due to a natural affinity between Calvinist Presbyterians and Calvanist Reformed 


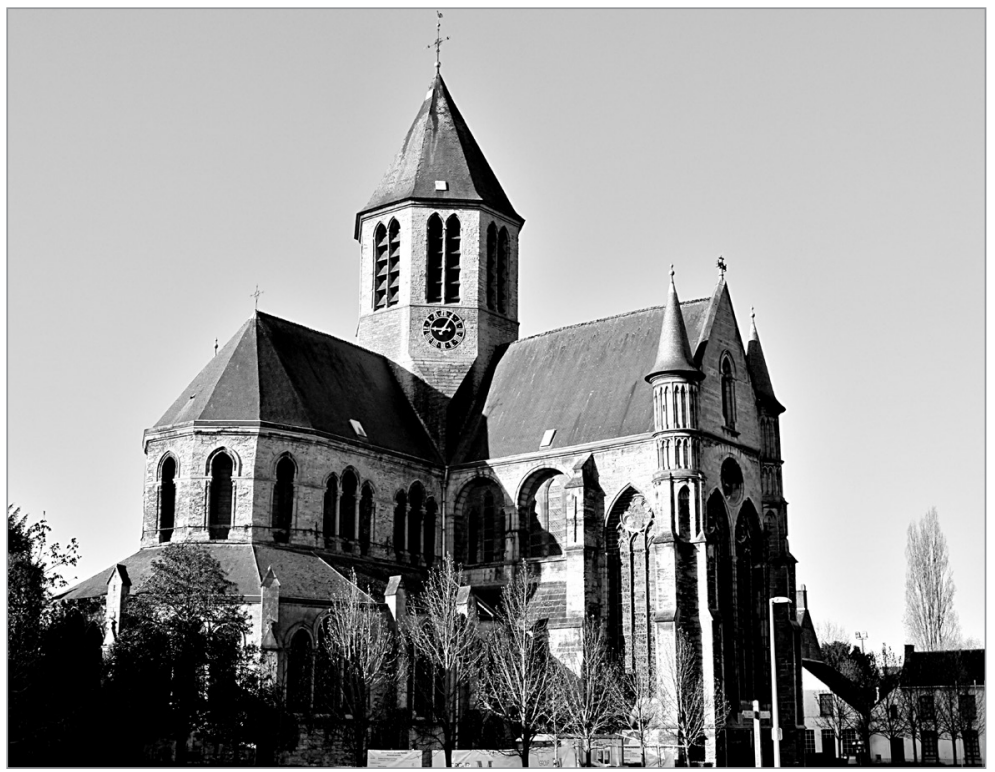

FIG. 7. VIEW OF SOUTH SIDE OF OUR LADY OF PAMELE, OUDENAARDE, BELGIUM (1234-1264). | ZAIRON.

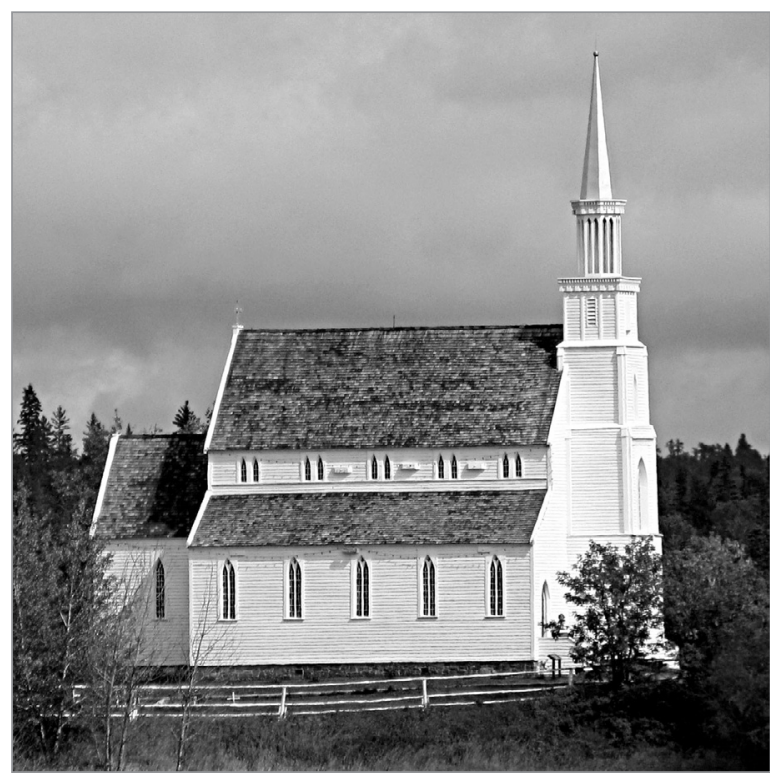

FIG. 8. VIEW OF THE SOUTH SIDE OF HOLY TRINITY ANGLICAN CHURCH, STANLEY MISSION, SK (1854-1860). UNKNOWN ARCHITECT. | KRISTIE DUBÉ. immigrants, the Canadian Presbyterian Church sent a minister (Kálmán Kovácsi) to the colony to provide assistance. ${ }^{19}$ From that point on, the congregation was referred to as Presbyterian; however, it should still be noted that the bulk of the congregation was, in fact, Reformed, or some blend of the two. Consequently, an analysis that lumps the congregation under the banner of Presbyterianism fails to account for the more complex narrative.

The surviving documentation for Bekevar church gives a fair amount of insight into the aspirations of both the colony founder (Szabo), and the church committee. Szabo's initial plan called for the construction of a stone church. ${ }^{20}$ As previously mentioned with Kaposvar church, stone was not an easily accessible material in Saskatchewan due to labour restraints. It was used mostly in town churches for congregations that were large and well enough established to support the extremely high cost associated with it (such as St. Mary's, fig. 5). It was much less common in rural areas, so the intention to build a stone structure in Bekevar reveals a fair amount about Szabo's ambitions. The use of stone indicates that Szabo intended the congregation, and possibly the larger colony to become permanent. ${ }^{21}$ The choice of stone, despite the limitations, is also an indication that Szabo was looking toward Kaposvar colony.

Szabo was not the only one looking to Kaposvar; Bekevar's building committee was also influenced by their Hungarian predecessors. While the two colonies shared a language and cultural background, it did not mean that they were joined in their aspirations. In fact, evidence suggests that the relationship between the two congregations was fairly antagonistic. The French Catholic nature of the Kaposvar colony was described as being a threat to Bekevar's own Presbyterian/Reformed religion, the Hungarian language, and Hungarian heritage. Bekevar's congregation felt a need to respond to this perceived threat and make a "tacit claim for superiority" to become the bearer of "Western Canadian Hungarian identity."22 Beyond simply constructing a place of worship, Szabo and the committee were aiming to create a competing beacon of Hungarian culture in the middle of the Prairies.

Bekevar Church indeed does function as a beacon of Hungarian culture, albeit not as originally planned. By 1911, the estimated cost of "several thousand dollars" proved too much for the congregation and the committee realized that its plans were not possible without access to more cost-effective labour (such as at Kaposvar), so they decided to adopt a new plan calling only for "a beautiful and large church that will be worthy of the congregation." ${ }^{23}$ While the new plan was not overly descriptive, it did specify the size being "large," and that it was "worthy" of the aspirations of the congregation. In order to achieve a large size, the committee decided to use wood instead, as it was substantially cheaper. While stone was viewed as a more permanent material, wood was viewed as being 


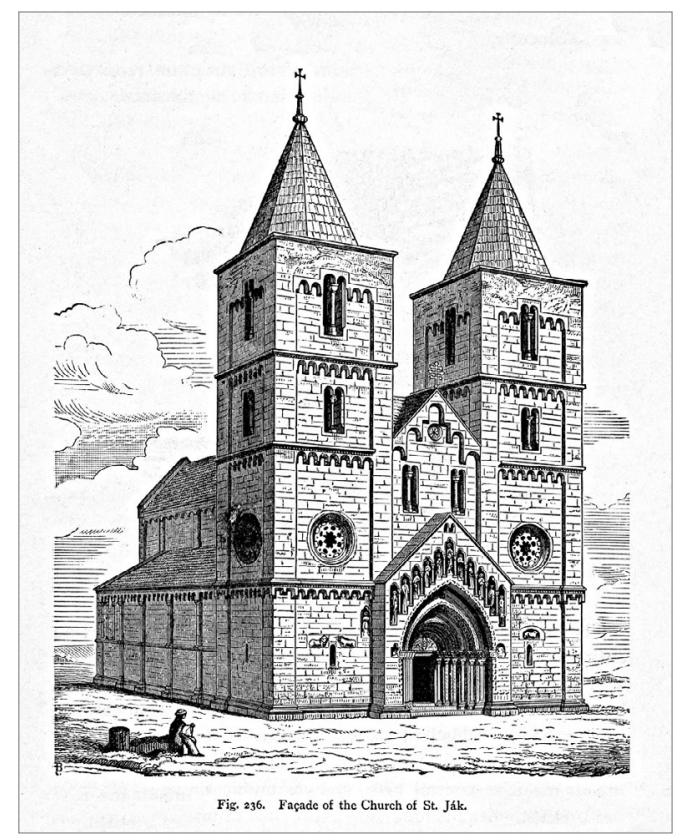

FIG. 9. 1881 ENGRAVING OF THE VIEW OF THE WEST FAÇADE OF ST. GEORGE'S CHURCH, JÁK, HUNGARY. | BENEDICTINE-PENN STATE LIBRARIES COLECTION.

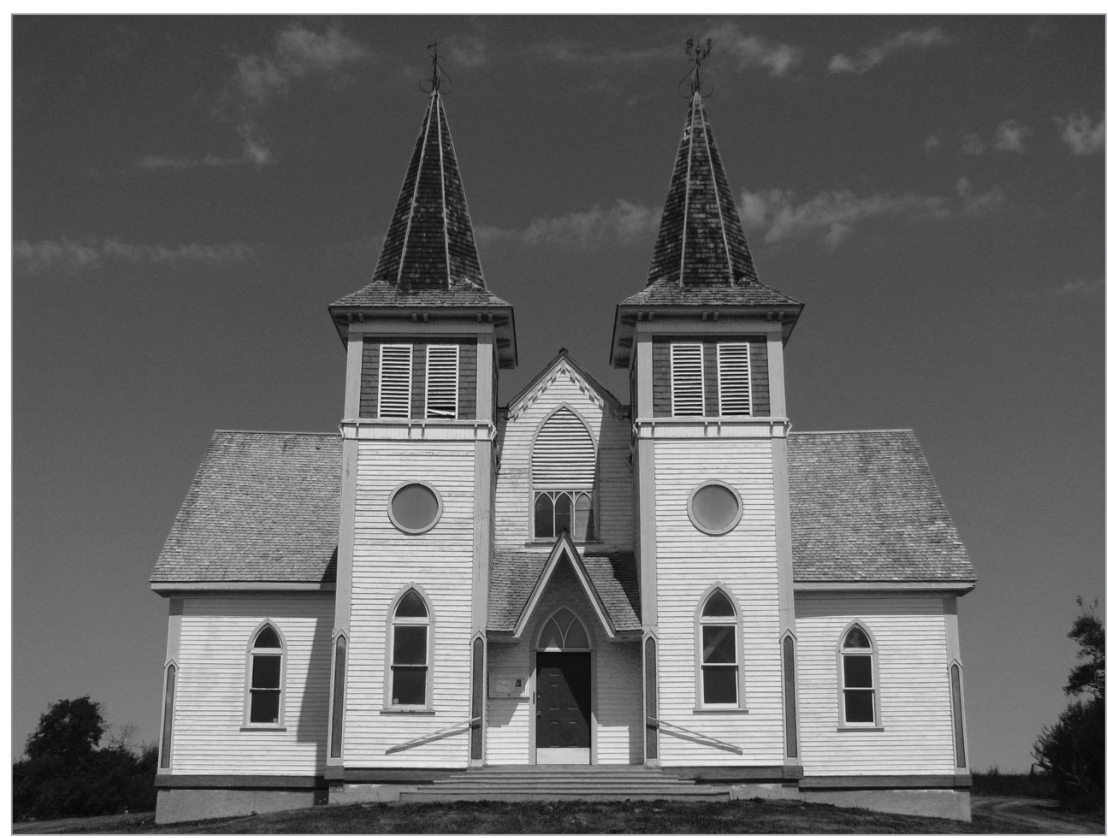

FIG. 10. VIEW OF THE WEST FAÇADE OF BEKEVAR PRESBYTERIAN CHURCH, BEKEVAR, RM 94, SK (1912). UNKNOWN ARCHITECT. | KRISTIE DUBÉ. somewhat temporary. ${ }^{24}$ It is therefore unusual to have overly large wooden churches in Saskatchewan, though there are some notable exceptions, such as Holy Trinity Anglican Church at Stanley Mission (1854-1860, fig. 8). However, Bekevar's committee was looking to compete with Kaposvar, and so needed to create something that was similarly arresting. They chose to accomplish this feat by adopting the features of a great medieval church.

St. George's Church in Ják, Hungary (thirteenth century, fig. 9), was used as a model for the façade of Bekevar church. It is easy to see how St. George's motif of a double-gable façade nestled between twin towers with round windows was taken up for use at Bekevar (figs. 9 and 10). As previously mentioned with Kaposvar, the use of twin towers in a small church is often done to link it to great churches. The link to St. George's also serves to link the congregation to their native Hungary, but there is a further association embedded in the history of the church. St. George's church was also heavily restored (1876-1904) by Frigyes Schulek, the same architect responsible for renovating Matthias Church, the model for Kaposvar's façade (fig. 4). ${ }^{25}$ The choice of another Schulek church must be viewed as a direct response to Kaposvar. One could make the argument that the nod to Kaposvar could be viewed as a sign of respect. However, the opulent threeday consecration event that they held (typically a one-day event) counters this assertion. The event was lauded as being designed to make a claim for superiority over Kaposvar Church, and its larger colony. ${ }^{26}$ Beyond simply tying themselves to their homeland, Bekevar's congregation members were also thinking of themselves in terms of the larger HungarianCanadian identity. In this case it is an antagonistic relationship, but nevertheless one that shows a concept of a separate ethnic identity within the larger Canadian identity.
Traditional lenses, such as denominational and architect-driven ones, have much to offer in furthering the study of related macro-histories. However, a re-examination such as this, of two churches that had previously been explored under a denominational lens, shows how much can be left out concerning the micro-histories. ${ }^{27}$ In this instance, a denominational approach leaves out much of the minority immigrant narrative. At Kaposvar, the Hungarian congregation's drive to equal the splendour of Budapest's medieval glory, as well as a passionate Belgian family's drive to create a church fit for kings, were both part of the immigrant narrative. At Bekevar, the congregation's desire to create a strong Hungarian beacon within the bounds of Canada, as well as its competitive nature, were also distinctly part of the minority immigrant story. The narratives of these two churches reveal an important part of Saskatchewan's early cultural development, one that existed alongside the Anglo-French normative 
perspective. It is paramount that we give greater attention to these micro-histories, to ensure that we present more of the ethnic diversity within Saskatchewan's architectural history.

\section{NOTES}

1. František Palacký, December 28, 1839, Memorandum, in Henry Cleere, 1984, Approaches to Archaeological Heritage, Cambridge, Cambridge University Press, p. 14.

2. Dubé, Kristie, 2013, "Optimism and Competition in Saskatchewan's Rural Gothic Revival Churches in the Early Twentieth Century," Journal of the Society for the Study of Architecture in Canada, vol. 38, no. 1, p. $75-83$.

3. Some of the research for this article was made possible by the Social Sciences and Humanities Research Council through their Canada Graduate Scholarship program. I am also greatly indebted to the guidance and generosity of Malcolm Thurlby, whose wealth of knowledge I have been privileged to access.

4. Due to a general shortage of highly skilled labour in rural Saskatchewan in the early twentieth century, it was rather uncommon to have access to a trained architect. Most churches were thus constructed by carpenters.

5. Hodsman, Roy (ed.), 1988, Archdiocese of Regina: A History, Regina, Archdiocese of Regina, p. 103.

6. "Opening of Kaposvar Church," November 10, 1908, Esterhazy Observer, in Jean Pask, 1986, Kaposvar: A Count's Colony, 1886-1986, Saskatchewan Archives Board (SAB), p. 45.

7. Perin, Roberto, 2003, "Langevin, Adélard," in Dictionary of Canadian Biography, vol. 14, n.p., University of Toronto and Université Laval, [http://www.biographi.ca/en/bio/langevin_adelard_14E.html], accessed April 17, 2018.

8. Kovacs, Martin L., 1974, Esterhazy and Early Hungarian Immigration to Canada, Regina, Canadian Plains Studies, p. 3; Pask, Kaposvar: A Count's Colony, p. 14; McLennan, David, 2008, Our Towns: Saskatchewan Communities from Abbey Park to Zenon Park, Regina, University of Regina Canadian Plains Research Center, p. 117.

9. White, Walter H., winter 1910-1911, Occasional Paper, no. 101, SAB, p. 23, 26; Esterhazy, Paul O., May 30, 1885, letter to J. Lowe
(Secretary of the Department of Agriculture), in Jason F. Kovacs, Spring 2006, "Con Artist or Noble Immigration Agent?: Count Esterhazy's Hungarian Colonization Effort, 1885-1902," Prairie Forum, vol. 31, no. 1, p. 41-42.

10. Pask, Kaposvar: A Count's Colony, p. 14; McLennan, Our Towns: Saskatchewan Communities, p. 14; Jozsef, Lengyel and Babijàk Jànos (settlers), 1902, The Hungarian Colony of Esterhaz, Assiniboia, North-West Territories, Canada, Ottawa, Government Printing Bureau, in Kovacs, Esterhazy and Early Hungarian Immigration, p. 91, 103; Woodcutter, Rev. Francis, 1902, The Hungarian Colony of Esterhaz..., in Kovacs, Esterhazy and Early Hungarian Immigration, p. 77-78; Kovacs, "Con Artist," p. 40.

11. Anderson, Alan 2006, "Hungarian Settlements," The Encyclopedia of Saskatchewan, [http://esask.uregina.ca/ entry/hungarian settlements.html], accessed January 2012.

12. "Our Lady of Assumption: Kaposvar Church Centennial, 1907-2007" 2007, Kaposvar, Kaposvar Historic Society, p. 2-3.

13. Thurlby, Malcolm, 1990, "The Church of Our Lady of Immaculate Conception, at Guelph: Puginian Principles in the Gothic Revival Architecture of Joseph Connolly," Society for the Study of Architecture in Canada Bulletin, vol. 15, no. 2, p. 35; Thurlby, Malcolm, 2016, "The Roman Catholic Churches of Joseph Connolly (1840-1904): The Adaptation of Pugin's True Principles and Aspects of Irish Identity in Ontario," in Timothy Brittain-Catlin, Jan De Maeyer, and Martin Bressani (eds.), Gothic Revival Worldwide: A.W.N. Pugin's Global Influence, Leuven, Leuven University Press, p. 76-93.

14. Hodsman, Archdiocese of Regina, p. 103.

15. "Our Lady of Assumption: Kaposvar Church Centennial," p. 4.

16. I am indebted to Professors Thomas Coomans and Malcolm Thurlby for advice on the Belgian associations of Kaposvar.

17. Van Assche, Auguste, 1883, L'Église de NotreDame-de-Pamela à Audenarde, Belgium, Gand.

18. Kovacs, Esterhazy and Early Hungarian Immigration, p. 45; Anderson, "Hungarian Settlements," op. cit.; Kovacs, Martin L., 1982, "The Saskatchewan Era, 1885-1914," in Nándor F. Dreisziger M.L. Kovacs, Paul Body, and Bennett Kovrig, Struggle and Hope: The Hungarian-Canadian Experience, Toronto, McClelland and Stewart Limited, p. 64.
19. Kovacs, Esterhazy and Early Hungarian Immigration, p. 43

20. Canadian Magyar Farmer, "Proposal, 26 June 1911," in Martin L. Kovacs, 1980, Peace and Strife: Some Facets of the History of an Early Prairie Community, Kipling, Kipling District Historical Society, SAB, p. 27; Kovacs, Peace and Strife, p. 27.

21. Kalman, Harold, 2000, A Concise History of Canadian Architecture, New York, Oxford University Press, p. 255.

22. Doka, Rev. K.C. and Martin L. Kovacs, n.d., in Kovacs, Peace and Strife, p. 20, 31, 35, 44, 43.

23. Canadian Magyar Farmer, "Proposal," p. 27; Kovacs, Peace and Strife, p. 27.

24. Kalman, A Concise History of Canadian Architecture, p. 255.

25. Wischermann, Heinfried, 2004, "The Romanesque Period in Central Europe," in Rolf Toman (ed.), Romanesque Architecture, Sculpture, Painting, European Union, Könemann, p. 254.

26. Doka and Kovacks, Peace and Strife, p. 20, 31, $35,44,43$.

27. Dubé, "Optimism and Competition in Saskatchewan's," p. 75-83. 